\title{
A Study of Relationship of Service Quality, Customer Satisfaction and Service Value with Customer Loyalty of Life Insurance Customers in India
}

\author{
Prof. (Dr) Sanjiv Mittal \\ Dean University School Of Management Studies, GGS IP University, Dwarka, Delhi-110078 (INDIA)
}

\begin{abstract}
While the Indian Life insurance Industry was privatized and liberalized in early 1990's, it's still underpenetrated and in an emerging state. With the focus shifting to customer centered strategies, retaining customers has become a key differentiator. The paper develops and empirically tests the relationship between the service encounter constructs of service quality, customer satisfaction and service value with customer loyalty related intentions in life insurance services in India. A second order scale of service quality was developed and tested by integrating the American and Nordic approach to Service Quality using exploratory factor analysis and confirmatory factor analysis. The constructs of Customer satisfaction, service value and Behavioral intentions were validated using confirmatory factor analysis. Two competing models of effects of the three service encounter constructs on Behavioral Intentions were tested using structural equation modeling (SEM). The results show that Service quality is a second order construct consisting of the dimensions of Core service. Service Delivery, Sales Agent Quality, Tangibles and Empathy. The process dimensions (sales Agent Quality and Service delivery) are most important in overall service quality perceptions. The effect of service quality on positive behavioral intentions is both direct and indirect with the moderating effect of service value and customer satisfaction being significant.
\end{abstract}

Keywords: Life Insurance; Service Quality; insurance service quality; relationship between service quality and customer satisfaction

\section{Introduction}

The Indian Life Insurance market is still under penetrated and can be considered in the emerging state.

Indian insurance industry ranks 51 across the world in terms of penetration. The Indian Life Insurance premium is a mere 1.5 percent of the GDP, compared to 11.6 percent in South Korea (Palande, Shah and Lunawat, 2003). However, market penetration and per capita coverage is likely to increase with enhanced growth rates in household incomes (Andrade et al, 2012). According to Insurance Regulatory and Development Authority (IRDA), the life insurance industry witnessed a growth of $7.5 \%$ in weighted new business premium collections in the first quarter of FY2014-15. The challenge facing most life insurance companies is that they are offering similar policies and hence product differentiation is difficult to achieve. Deregulation of financial services industry 1990's onwards and reforms have contributed to the relatively fast pace of change as a result of which incumbent firms are facing greater environmental uncertainty. As a result, providing superior service quality has assumed strategic importance in Life Insurance services in India.

The outcomes of life insurance purchase are often delayed and therefore the consequences of a purchase are not immediate which therefore does not immediately lead to overall customer satisfaction. The future benefits of the insurance "product" purchased are difficult to foresee and take a long time to "prove" its effects (Crosby and Stephens, 1987). Hence the rapport between retail employees and customers becomes more important in high social interaction context (Gremler and Gwinner's, 2008).

\section{Significance of the Study}

There's a noticeable lack of studies on Service Quality and its consequences in emerging economies like India though services are one of the fastest growing sectors in emerging economies (Saha, G.C. \& Theingi (2009). Therefore, the present study aims to contribute to academic research by empirically testing and evaluating the direct and indirect effects of service encounter constructs on customer consequences in Indian Life services to determine the best fitting model. 


\section{Review of Literature}

Prior studies into the linkages of Service Quality (SQ), Service Value (SV) and Customer Satisfaction (CS) with Behavioural Intentions (BI), showed that there was consensus on some of the direct relationships between the constructs as follows: Service Quality is significant antecedent of Customer Satisfaction; Service Quality perceptions influence Service Value perceptions; Service Value is significant antecedent of Customer Satisfaction; Customer Satisfaction has significant effect on Behavioral Intentions; Service Value has significant effect on Behavioral Intentions (Cronin et al, 2000). They concluded that "model structure appeared to be highly dependent on the nature of the study" and called for further studies in varied service contexts to resolve the ambiguity in the path of service quality with customer loyalty related behavioural intentions. This study evaluates the two competing models named as the Direct Effects and Indirect Effects models of effects of service quality, customer satisfaction and service value on behavioural intentions to determine the best fitting model. Studies by Cronin et al, (2000) and Durvasula et al., (2004) found evidence of mediating role of Service Value in relationship of SQ with BI. Park et al., (2006) and Parasuraman and Grewal (2000) in their studies, empirically established that there is a significant association between customer perceptions of Service Value and their loyalty related future intentions. Thus it's hypothesized that -

H1a: Service Quality has a significant and positive effect on Customer Satisfaction.

H1b: Service Quality has a significant and positive effect on Service Value.

H1c: Service Quality has a significant and positive effect on Behavioral Intentions.

H1d: Customer Satisfaction has a significant and positive effect on Behavioral Intentions.

H1e: Service Value has a significant and positive effect on Behavioral Intentions.

Tsoukatos and Rand (2006), empirically tested the path of Service Quality with Behavioral Intentions of repurchase and positive word-of-mouth through Customer Satisfaction with life Insurance customers in Greece and found that service quality dimension of Tangibles had significant indirect effect on Behavioral Intentions of positive Word of Mouth and Repurchase (mediated by Customer Satisfaction). Durvasula et al, (2004) empirically established that Service Quality of agents as perceived by life insurance customers has significant indirect effect (mediated by Customer Satisfaction and Service Value (Perceived Value) on their future Behavioral Intentions of repurchase and positive recommendations. Hence it's hypothesized that

H2a: Customer Satisfaction mediates the effect of Service Quality on Behavioral Intentions

H2b: Service Value mediates the effect of Service Quality on Behavioral Intentions

Hellier et al (2003) in their study with customers of general insurance found that found that customer perceptions of Service Value influence brand preference both directly and indirectly through Customer Satisfaction. Hence it's hypothesized that

H3: Service Value effect on Behavioral Intentions is direct and indirect i.e. moderated by Customer Satisfaction.

\section{Methodology}

Exploratory and descriptive research technique was used to explore the service quality aspects and to test them further. Target sample size of 350 was selected; Data was collected from two largest Life insurers that is Life Insurance Company of India (LIC) and ICICI Prudential.

A list of 38 items was generated through literature review and subject to content validation through review with experts. A pilot study was done on 30 respondents who were existing customers of life insurance services in NCR of Delhi to test the reliability and content validity of the questionnaire. After the analysis of factors items five were extracted and labeled as - Service Delivery, Core Service, Tangibles, Sales Agent Quality and Empathy, where these five factors accounted for 66.5 percent of the total variance explained. All the five dimensions were tested for reliability and found to be acceptable with Cronbach alpha scores greater than 0.7.A second order reflective model was formulated and tested for purpose of structural path analysis as per the approach recommended by Brady and Cronin (2001) so that the Nordic and American perspectives of SQ can be integrated. The second order reflective model was found to be of acceptable fit based on indices of fit after suitable modification as can be seen in the following Fig. 1. 


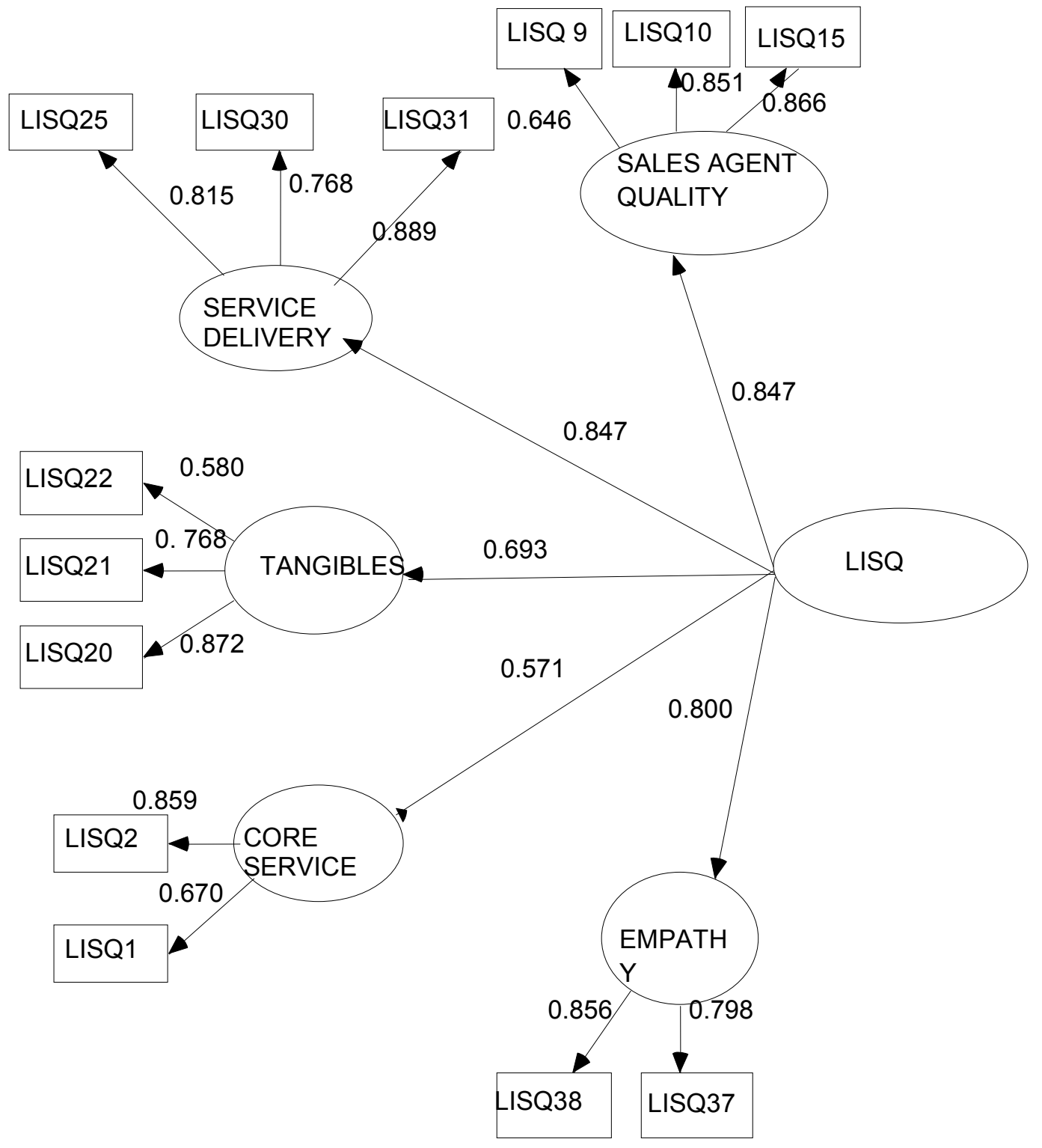

Fig. 1: Life Insurance Service Quality-Second Order Model

The second order model of Service Quality was selected for further analysis in structural model and results were interpreted.

\section{Results}

Service quality is a five dimensional (factor) multilevel hierarchical construct consisting of primary dimensions of Service Delivery, Core Service, Tangibles, Sales Agent Quality and Empathy. Service Delivery and Sales Agent Quality are the two most important dimensions of Service Quality followed by Empathy, Tangibles and Core Service.

Structural equation modeling was employed to test the relationships that may exist between Service Quality, Customer Satisfaction, Service Value and Behavioral Intentions. The structural equation model included one exogenous variable (Service Quality), and three endogenous variables (Customer Satisfaction, Service Value, and Behavioral Intentions). 


\section{Discussion and Conclusions}

The results show that customers evaluate their overall perception of Service Quality in life insurance services by assessing the five component (reflective) Service Quality dimensions of Core Service, Tangibles, Service Delivery, Sales Agent Quality and Empathy. The dimensions of Sales Agent Quality and Service Delivery were found to be most important based on the regression weights of the measurement model followed by Empathy, and Tangibles (Fig.1).

\section{References}

[1] Andrade, N., Balasubramanian, R., Ehrbeck, T., and Madgavkar, A., (2012) "India Life Insurance, 2012, Fortune Favours the Bold”, Mckinsey Global Institute, MGI study.

[2] Bitner, M.J., Booms, B.H. and Mohr, L.A. (1994), "Critical service encounters: the employee's viewpoint", Journal of Marketing, Vol. 58, October, pp. 95-106

http://dx.doi.org/10.2307/1251919

[3] Brady, M. K. \& Cronin, J. J. (2001), "Some new thoughts on conceptualizing perceived service quality: A hierarchical approach," Journal of Marketing, Vol. 65 No 3, pp:34-49.

http://dx.doi.org/10.1509/jmkg.65.3.34.18334

[4] Crosby, L. A. and Stephens, N. (1987) 'Effects of relationship marketing on satisfaction, retention, and prices in the life insurance industry', Journal of Marketing Research, Vol. 24, November, pp. 404-411.

http://dx.doi.org/10.2307/3151388

[5] Durvasula, S., Lysonski, S., Mehta, S.C. and Peng Tang, B. (2004), "Forging relationships with services: the antecedents that have an impact on behavioral outcomes in the life insurance industry", Journal of Financial Services Marketing, Vol. 8 No. 4.

http://dx.doi.org/10.1057/palgrave.fsm.4770129

[6] Gremler, D. D., Gwinner, K.P. (2008). Rapport-building behavior used by retail employees. Journal of Retailing, Vol. 84 No 3,pp: 308 - 324.

http://dx.doi.org/10.1016/j.jretai.2008.07.001

[7] Grönroos, C. (1984), “A Service Quality Model and its Marketing Implications.," European Journal of Marketing, Vol. 18 No 4, pp:36-44

http://dx.doi.org/10.1108/EUM0000000004784

[8] Hellier, Phillip K., Gus M. Geursen, Rodney A. Carr and John A. Rickard (2003), —Customer Repurchase Intention: A General Structural Equation Model,॥ European Journal of Marketing, Vol. 37, No. 11/12, pp. 1762-800.

http://dx.doi.org/10.1108/03090560310495456

[9] Palande, P.S., Shah, R.S., and Lunawat, M.L. (2003), Insurance in India: Changing Policies and Emerging Opportunities, Sage Publications, India.

[10] Parasuraman, A. \& Grewal, D. (2000), "The impact of technology on the quality-value loyalty chain: A research agenda," Academy of Marketing Science Journal, Vol.,28, No.1

[11] Saha, G.C. \& Theingi (2009)., "Service quality, satisfaction, and behavioral intentions: A study of low- cost airline carriers in Thailand.," Managing Service Quality, Vol. 19 No. 3

http://dx.doi.org/10.1108/09604520910955348

[12] Tsoukatos, E. and Rand, G.K , (2006),'Path analysis of perceived service quality, satisfaction and loyalty in Greek insurance," Managing Service Quality, Vol. 16 No. 5.

http://dx.doi.org/10.1108/09604520610686746 